\title{
What is Brand? Some Insights in the Historical Development
}

\author{
Fazal Ur Rehman ${ }^{1, *}$, Rosman Bin Md Yusoff², Fadillah Binti Ismaili3, Farwida Javed ${ }^{4}$ \\ 1,3FPTP, Universiti Tun Hussein Onn Malaysia, Parit Raja, Johor, Malaysia \\ 2PPUK, Universiti Tun Hussein Onn Malaysia, Parit Raja, Johor, Malaysia \\ ${ }^{4}$ COMSATS Institute of Information Technology, Attock Campus, Pakistan \\ fazal_marwatpk@yahoo.com
}

\begin{abstract}
The aim of this study is to enhance understanding in the philosophy of the brand along with its historical development around the world. Its main purpose is to clarify the nature of the brand, its origination, ancient phase, digital phase and the future of branding. This study is based on the secondary source to clarify the gap of knowledge, understand the thought of branding and review the literature in regard to its historical development and evaluation around the world. It has found that brand is a tangible and non-tangible asset of a business that presents a unique identity and reputation among a wide set of competitors, and is perceived as a market leader in a particular industry. The study has found that branding is the best practice to enhance the image and value of business among targeted consumers. It has anticipated that branding is the technique to gain competitive advantage and accomplish the objectives of a business. This study presents a comprehensive overview of the nature of branding along with its wide historical development (origin, ancient phase, digital phase, future phase) around the world.
\end{abstract}

Keywords: Branding, History of Branding, Forms of Branding

\section{Introduction}

This study sheds light on the philosophical conception of branding and provides a review of its historical development in a short conclusion around the world. Notably, this study presents the definitions of a brand, its origin, ancient phase, digital phase and sheds light on the future of branding to increase understanding in its historical evaluation. The term brand has very old and sound history around the world and researchers have defined it in a different context over the passage of time. However, in the first stage, this study highlights the views and thoughts of various researchers about the philosophical conception of the brand, followed by its historical origin where literature has mentioned the birth of branding, packaging and labelling in ancient time (Maran and Stockhammer, 2012; Demirdjian, 2005). Literature has mentioned the evidence of potter stamps usage during the period of the Roman Empire and ancient Greece in past back around $6^{\text {th }}$ century BCE, on the bricks, pottery, storage containers and fine ceramics (Peacock, 1982), and still is a necessary part of every business to support their trade in a wide range. However, the prime objective of this study is to enhance understanding in the conception of branding and summarize its wide historical development in a short conclusion. This study is vital to highlight the current digital trend of branding in an economic, cultural and social context and the future of smart branding to compete in the modern era. Therefore, in the next section, it discusses the digital phase of branding followed by the future of branding, while, the conclusion is the last part of this study.

The Nature of Brand: The term brand is the value, position and image of a name, design, symbol, product and service that keeps it apart from the rest due to its uniqueness in the target market (Fahy and Jobber, 2015), and consumers perceive it superior to other. The conception and practice of brand has been widely used in the field of marketing and advertising around the world. Precisely, it may be a series of marketing communication that apart it from competitors in an industry, and creating a good impression on the mind of consumers in the target market. Concisely, the brand is a set of tangible and non-tangible attributes of a person, service, product, place, or a business to create awareness in the target market, avail a unique identity, reputation, and a wide set of activities starts from product innovation and invention to final marketing communication (Sammut-Bonnici, 2014). "A brand is a distinguish identity and unique name and/or symbol (such as logo, trademark, or package design) intended to recognize the goods or services of either one seller or a group of sellers, and to differentiate those goods or services from those of competitors. A brand thus give signals to the customer, is the source of the product, and protects both the customer and the producer from competitors who would attempt to provide products that appear to be identical" (Aaker, 1991). 
In brief "brand is a name, term, sign, symbol or design, or a combination of these, intended to identify the goods or services of one seller or a group of sellers to differentiate them from those of competitors" (Tasci and Kozak, 2006). The brand is "the company's promise to deliver a specific set of features, benefits, services, and experiences consistently to the buyers" (Kotler 2005 p. 250). However, literature has mentioned brand identity, brand communication which consists logos and trademarks, brand awareness, brand loyalty and different branding strategies to build a brand in the target market (Ghodeswar and Bhimrao, 2008), and branding is the most valuable thing to differentiate the business process and product from competitors in the $21^{\text {th }}$ century. Notably, a brand name is a memory heuristic, a word, phrase, sign, symbol, design and a convenient way to get preference among products while purchasing, and keep it apart from competitors (Franzen, Giep, Moriarty, and Sandra, 2015), whereas trademark is a type of brand that is legally protected. In addition, brand identity is the set of a name, design, image, slogan, vision, written style, and a particular front image etc. That keep it separate from other brands in a market (Kotler and Philip, 2009; Franzen, Giep, Moriarty, and Sandra, 2015), and possess four levels of meaning such as attributes, benefits, values and personality.

Whereas brand attributes are the set of labels, while benefits are the translation of emotions that communicate an attribute among consumers. Values are the features that can attract consumers toward product and personality is the social or emotional attachment, and association of a specific person with a brand (Kotler and Philip, 2009). Brand identity includes trademark, communication and visual appearance of a brand (Neumeier and Marty, 2004), while, brand trust is the inherent believability that creates a strong foundation to connect all stakeholders and building commitment with them (Chaudhuri and Arjun, 2002). However, name, logo, tagline or catchphrase, graphics, shapes, colors, sounds, scents and tastes, movements are the popular elements of the brand (Pearce, 2013), and initialism, descriptive, alliteration and rhyme, evocative, neologisms, foreign word, founders name, geography, personification, punny, and combination are the popular styles of brand names (MerriamAssociates.com, 2018). In addition, "brand equity is the value of brand in marketplace both for branding company and the users" (Keller and Lane, 2003), and "brand equity provides a common denominator for interpreting marketing strategies and assessing the value of a brand; and that there exist many different ways in which the value of a brand can be manifested or exploited to benefit the firm" (Keller 1993; Keller 1998). Likewise, brand image is the perception, value and emotional attachment of consumers with a particular product. Such as "brand image is the reasoned and emotional perceptions of consumers attached to specific brands" (Low \& Lamb, 2000), "the set of beliefs, ideas, and impression that a person holds regarding an object" (Kotler, 2001).

It is the "consumer's perception and feeling towards a brand shaped by direct/indirect brand experiences, which captures cognitive, sensory, and emotional aspects. These are reflected by the three dimensions of mystery, sensuality, and intimacy" (Roberts, 2004, 2006). Moreover, "Brand awareness is related to the strength of the brand node in memory, as reflected by consumers' ability to identify the brand under different conditions. Brand awareness consists of; 1) brand recognition is reflecting the ability of consumers to confirm prior exposure to the brand and 2) brand recall is reflecting the ability of consumers to retrieve the brand, when give the product category, the needs fulfilled by the category, or some other type probe as a cue. Brand awareness can be characterized according to depth and breadth. The depth of brand awareness concerns with the likelihood that the brand can be recognized or recalled and the breadth of brand awareness relates to the variety of purchase and consumption situations in which the brand comes to mind" (Keller 1993; Keller 1998; Tuominen, 1999), while brand association is the consumers psychological and emotional connection with the brand.

Origin of Brand: The word brand has originated from the Old High German word "Brinnan", someone believes it has originated from the old English word "Byrnan or Biernan," or Middle English word such as "Birnan or Brond" and perceived its meaning as firebrand or a burning piece of wood (Merriam-Webster, 1983). In the same way, a study has explained that "the word brand comes from the 'Old Norse brandr', meaning to burn, and from these origins made its way into Anglo-Saxon countries and adopted the meaning of 'to be hot'. It was by burning that early man stamped ownership on his livestock, and with the development of trade buyers would use brands as a mean to distinguish between the cattle of one farmer from another" (Khan and Mufti, 2007). As in the very beginning and ancient age, torches were used to mark things such as 
livestock, furniture, pottery etc. to permanently burn the sign or symbol marks into the skin to show the association with a specific business group or brand (Simon and Schuster, 1997).

Likewise, Aaker (1991) has presented his views that the conception of the brand has originated from the practice to use a hot iron to make marks on the skin of livestock and other goods to affiliate the possession and declare its quality. However, branding and labelling have very ancient history and it is believed that the idea of branding took place 2700 BCE, when the ancient Egyptians started livestock branding to differentiate their cattle from other by burning the animal's skin with a hot iron to make sign or symbol on it (Wheeler, 1946). In addition, the ancient Egyptians used identity marks such as stamps on ceramics to practice the branding. Gradually, the people at that time realized the association of brands with the origin and ownership of products, and observed it as a guide toward quality. Different forms of branding had emerged in farming, pottery, and trade with the passage of time throughout Africa, Asia and Europe. Seals were used as quasibrands in Chinese culture (221-206 BCE), and in Harappan civilization at Indus Valley (3300-1300 BCE), and cylinder seals in ancient Greece and Rome around (3,000 BCE) for labelling of goods and property.

Ancient Phase: In the ancient civilization, the use of maker's marks was a famous tradition to recognize the business in Indian history dating back 1,300 BCE (Khan and Mufti, 2007), and the period is also known as Vedic period and Chyawanprash. The conception of the brand was also found in old Chinese civilization dating back 960 to 1127 CE and at that time "White Rabbits" was a famous brand of sewing needles in China (Eckhardt and Anders, 2008). During the period of cavemen, the painting of walls was one of the sources of branding in the history of France dating back 15,000 BC (Yenicioglu and Christodoulides, 2014), where Lascaux Caves is the famous wall in the French history. The marking and stamp of craftwork with the seals to declare the identity and ownership of products was a common practice in ancient civilization. Likewise, in the ancient Roman civilization, the inscriptions called titulus pictus was applied to indicate the place of origin, name of producers for goods such as pots, ceramics, amphorae, oil-lamps etc. for the recognition of products and to be perceived as a brand in the community at that time (Johnson, 2015), and Ennion was the famous brand of glasses at that time. During the period of $13^{\text {th }}$ century, the conception of maker's marks become evident of goods on a wide range in Europe. For instance, 1266 (England passed the Bakers Marking Law) maker's marks were the famous law to brand the bread in England (Martino, 1996), and Hallmarks was the famous brand of silver at that time. Many brands of old British civilization are still popular around the word such as Bass \& Company (brewery brand) and Twinings Tea (Colette, 2008). In the $18^{\text {th }}$ century, the Wedgwood \& Bentley was the famous luxury brand in China during the era of industrialization (Arvidsson, 2006).

Digital Phase: The development of the internet has upended and transformed consumers from the traditional economic and marketing functions into a more structured and standard way of buying and selling. Due to the advancement in information and communication technology, the significance of branding has been proliferating around the world (Askegaard, 2006). In the digital world, the concept of branding has become a part of culture and social statues among individuals as well as institutions (Smith, 2011), is perceived as a powerful ideoscapes and medias capes around the world (Cayla and Arnould, 2008; Askegaard, 2006), possess power to influence consumers personal and social relations in a significant way. In the age of industrial revolution, many companies are now increasingly streamline their efforts to specialize the activities of business and building brand to get the position (Lipiainen and Karjaluoto, 2015), as branding is perceived as a key factor of success in the digital era as compared to previous years. However, the knowledge of branding is limited in the digital era and a comprehensive understanding is required to provide a guideline for integrated communication practice (Keller, 2009; Lipiainen and Karjaluoto, 2015). In the digital era, building a brand has become more complex and multidirectional task due to availability of multiple option for consumers to create linkage, discuss and talk with other about a brand and has reduced the control of a business on its consumers (Lipiainen and Karjaluoto, 2015; Hennig-Thurau et al., 2010; Kaplan and Haenlein, 2010), and now businesses need to implement the more advanced branding strategies both in online and offline environment. Brand also required some unique branding strategies in the fragmented media environment to build a theoretical foundation, creating value in the digital era, and to establish a valuable relationship with different stakeholders (Lipiainen and Karjaluoto, 2015). 
Future Phase: The future of branding seems a more complex challenge for the companies due to rapid advancement in information, manufacturing, packaging, designing, processing and communication technology, and intense competition among brands around the world. Due to advancement in technology, the consumers are now able to get wide access to multiple brands, understand its features, share its information, and can get feedback about a brand from other users. In the future, the emergence of stronger consumers, the act of civil right movement, supervision of companies' commitment, the faster flow of information's, continues innovation, and the wide range of customers' social responsibilities may the greater challenges for brands in coming future (Hampf and Lindberg-Repo, 2011). The smart packaging of the brand will also be the crucial element of marketing strategies to catch the sight of buyers in stores (Faganel and Janes, 2015), and marketers will need to understand the buying process and experience of targeted consumers. It is also believed that some other factors such as; perpetual adaptation, radical rebranding, smart selling, advertising, instant entrepreneurship, artistic selling, convenience, and discreet consumerism might affect branding in coming future (Trendreports, 2015; Faganel and Janes, 2015).

\section{Methodology}

This study is based on the secondary source to clarify the philosophy of branding and review its literature in regard to historical development and evaluation around the world. This study has applied the techniques of unsystematic methods to present a comprehensive literature review of branding and its historical development. As the concept of branding has a sound history but seems scattered and needs to enhance the conception of smart branding. It has been widely used in the field of marketing, advertising and researchers have presented different views about the conception of branding with the passage of time. Therefore, this study has to search various databases using keywords such as; what is brand, the historical development of branding, the origin of branding, the ancient phase of branding, the digital phase of branding, future of branding, smart branding etc. However, the result of smart branding and the future of branding was quite small. Some articles were selected on the bases of citations and most relevant to the current study. Some previous theses were thoroughly studied to present the sound and pivotal literature on branding. This study has also widely searched about branding through google to reach the important sites and collect necessary information. However, all the relevant articles are listed in references in the last section of this study.

\section{Results and Discussion}

This study has found that brand is a tangible and non-tangible asset of a business that presents a unique identity, reputation among a wide set of competitors, and is perceived as a market leader in a particular industry. The study has found that branding is the best practice to enhance the image, value of a business, and sustain its position among targeted consumers. It has anticipated that branding is the technique to gain a competitive advantage, increasing market shares, add value to products and services, and accomplish the objectives of the business. It is the name, symbol, sign or design that associates with a particular product or service. However, the concept of branding took place 2700 BCE in Egypt when the owners of cattle and animals had started burning the skin with a hot iron to make a sign for differentiation, and gradually shown magnificent growth around the world. In the ancient civilization, Chinese, French, Roman, Indian and British have significant contribution in the development of branding. While in the current digital world, branding is perceived as a powerful device to influence the social and personal relations of consumers, and become a part of statues for every institution.

However, the future of branding seems complex due to rapid innovation, changes in market trend, and the conception of smart branding, advertising might be effective sources in coming years. This study is in line with Khan and Mufti (2007), who presented a comprehensive review to the historical development of branding and brand management practices but could not highlight the pivotal usage of branding in the digital world, and the concept of smart branding. However, this study is inline in the context of branding and its historical development. This study is also in line with Starcevic (2015) who highlighted the origin and historical development of branding in Africa, Asia and European civilization, and linked it with advertisement but could not provide any future direction. This study is inline in the context of branding, its origin and historical development. This study is also in line with Briciu and Briciu (2016) who presented a brief history of branding and highlighted it as a useful mechanism to spread business informations. However, this study is 
inline in the context of history of brand. The findings of this study imply that branding is a useful source to enhance the buying behavior and involvement of consumers in business practices, share interesting information's, and catch the attention of consumers. It is used as an instrument to improve the image of a business, positioning, add value, and convince consumers toward business. This study has presented a comprehensive overview of the nature and evaluation of branding around the world.

\section{Conclusion and Recommendations}

The aim of this study was to increase understanding in the conception of branding along with its historical evaluation and development such as its origin, ancient phase, digital phase, and the future of branding. The study has clarified that branding is the tangible and non-tangible uniqueness of a name, design, product or service that keeps it away from competitors and possess its own identity. The study has found that the conception of branding took place thousands year ago in Indian, Egyptian, Chinese, Roman and Greece, British, and German civilization in the form of burning skins, torches, stamps, walls painting, makers marks, and titulus pictus with the passage of time. The study has noted that in the digital era, now many companies are streamlining their efforts to specialize their manufacturing, and need more advanced branding strategies in an online and offline environment, and importance of relations with various stakeholders, while, the future of branding seems a complex challenge for many companies due to rapid innovation. It is recommended that future studies should be conducted through interviews based qualitative method to further explore the digital phase and future of branding.

\section{References}

Aaker, D. A. (1991). Managing Brand Equity. The Free Press, New York.

Arvidsson, A. (2006). Brands: Meaning and Value in Media Culture. London: Routledge.

Askegaard, S. (2006). Brands as a Global Ideoscape, in J. Schroeder and M. Salzer-Mörling (Eds.), Brand Culture, London: Routledge, 91-102.

Briciu, V. A. \& Briciu, A. (2016), A Brief History of Brands and the Evaluation of Place Branding, Bulletin of the Transilvania University of Braşov, 9(58), 137-142.

Cayla, J. \& Arnould, E. J. (2008). A Cultural Approach to Branding in the Global Marketplace. Journal of International Marketing, 16(4), 86-112.

Chaudhuri, A. (2002). Product class effects on brand commitment and brand outcomes: The role of brand trust and brand effect. Brand management, 10(1), 33-58.

Colette, H. (2008). Golden celebration for 'oldest brand. BBC News UK.

Demirdjian, Z. S. (2005). Rise and Fall of Marketing in Mesopotamia: A Conundrum in the Cradle of Civilization. In The Future of Marketing's Past: Proceedings of the 12th Annual Conference on Historical Analysis and Research in Marketing, Leighton Neilson (ed.), CA, Longman, Association for Analysis and Research in Marketing.

Dodd, E. C. (1961). Byzantine Silver Stamps, Dumbarton Oaks Studies, Washington, Dumbarton Oaks Research Library and Collection, 7, 23-35.

Eckhardt, G. \& Anders, B. (2008). Pulling the white rabbit out of the hat: consuming brands in imperial China. European Advances in Consumer Research, 8, 221.

Fahy, J. \& Jobber, D. (2015). Foundations of Marketing, $4^{\text {th }}$ Edition, McGraw-Hill's.

Faganel, A. \& Janes, A. (2015). Branding Trends 2020, Management International Conference, Slovenia, 2015.

Franzen, G., Moriarty, S. E. (2015). The Brand as a System. The Science and Art of Branding. $1^{\text {ST }}$ Edition, London: Routledge, 19.

Ghodeswar, B. M. (2008). Building brand identity in competitive markets: a Conceptual Model. Journal of Product \& Brand Management, 17(1), 4-12.

Hampf, A. \& Lindberg-Repo, K. (2011). Branding: The Past, Present, and Future: A Study of the Evolution and Future of Branding, Hanken School of Economics, Department of Marketing.

Hennig-Thurau, T., Malthouse, E. C., Friege, C., Gensler, S., Lobschat, L., Rangaswamy, A. \& Skiera, B. (2010). The impact of new media on customer relationships. Journal of Service Research, 13(3), 311-330.

Johnson, K. (2015). Review Ennion,' at the Met, Profiles an Ancient Glassmaker, The New York Times. Retrieved on 9/29/2018. 
Kaplan, A. M. \& Haenlein, M. (2010). Users of the world, unite! The challenges and opportunities of social media, Business Horizons, 53(1), 59-68.

Keller, K. L. (2009). Building strong brands in a modern marketing communications environment, Journal of Marketing Communications, 15(2/3), 139- 155.

Keller Kevin, L. (2003). Strategic Brand Management: Building, Measuring, and Managing Brand Equity, $2^{\text {nd }}$ Edition. Upper Saddle River, New Jersey: Prentice Hall.

Keller Kevin, L. (1993). Conceptualizing, Measuring and Managing Customer-Based Brand Equity, Journal of Marketing, 1, 1-22.

Keller Kevin, L. (1998). Strategic Brand Management Building, Measuring, and Managing Brand Equity, Prentice Hall: Upper Saddle River.

Khan, S. \& Mufti, O. (2007). The Hot History \& Cold Future of Brands, Journal of Managerial Sciences, 1(1), 7587.

Kotler, P. \& Armstrong, G. (2005). Principles of Marketing, 4th European edition, Essex, Pearson Education Limited.

Kotler, P. (2009). Principles of marketing, Pearson Education Australia. ISBN 9781442500419.

Kotler, P. (2001). A Framework for Marketing Management. Upper Saddle River, NJ: Prentice- Hall.

Lipiainen, H. \& Karjaluoto, H. (2015). Industrial branding in the digital age, Journal of Business and Industrial Marketing, 30(6), 733-741.

Low, G. S. \& Lamb, C. W. (2000). The Measurement and Dimensionality of Brand Associations, Journal of Product and Brand Management, 9(6), 350-370.

Maran, J. \& Stockhammer, P. W. (2012). Materiality and Social Practice: Transformative Capacities of Intercultural Encounters, Oxford, UK, Oxbow, 2012

Martino, T. (1996). Trademark Dilution, Clarendon Press, p. 21.

Marty, N. (2004). The Dictionary of Brand. pp.20.

Merriam-Webster. (1983). Webster's ninth new collegiate dictionary, Springfield.

Simon. \& Schuster. (1997). The branding of slaves, The review of Arts Literature, Philosophy and the Humanities.

Merriam Associates. (2018). Beyond Name and Logo: Other Elements of Your Brand. Retrieved on 9/30/2018.

Peacock, D. C. S. (1982). Pottery in the Roman World: An Ethnoarchaeological Approach, Longman, 121-25.

Roberts, K. (2004). Love marks: The future beyond brands, 1st ed. New York: Powerhouse Books.

Roberts, K. (2006). The love marks effect: Winning in the consumer revolution. New York: Powerhouse Books.

Smith, T. (2011). Brand Salience Not Brand Science: A Brand Narrative Approach to Sustaining Brand Longevity, The Marketing Review, 11(1), 25-40.

Starcevic, S. (2015). The Origin and Historical Development of Branding and Advertising in the Old civilizations of Africa, Asia and Europe. Marketing, 46(3), 179.

Sammut-Bonnici, T. (2014). Brand and Branding, Wiley Encyclopedia of Management, John Wiley \& Sons, Ltd.

Tasci, A. \& Kozak, M. (2006). Destination brands vs destination images: Do we know what we mean? Journal of Vacation Marketing, 12(4), 299-317.

Trendreports. (2015). Branding Trend Report.

Tuominen, P. (1999). Managing Brand Equity, Turku School of Economics and Business Administration.

Wheeler, H. (1946). The Miracle of Man, London, Longacre.

Yenicioglu, B. \& Christodoulides, G. (2014). Branding in the age of digital connectivity, Henley Business School, University of Reading. 